\title{
Physico-Chemical Analysis of Water from Harahi and Gangasagar Ponds Located in Darbhanga District
}

\author{
Maryam Parween ${ }^{1}$, Shailza Verma ${ }^{2 *}$, Subhra Sahoo ${ }^{3}$, Arindam Kumar ${ }^{4}$, Priyanka ${ }^{5}$, Jyoti Mishra ${ }^{6}$
}

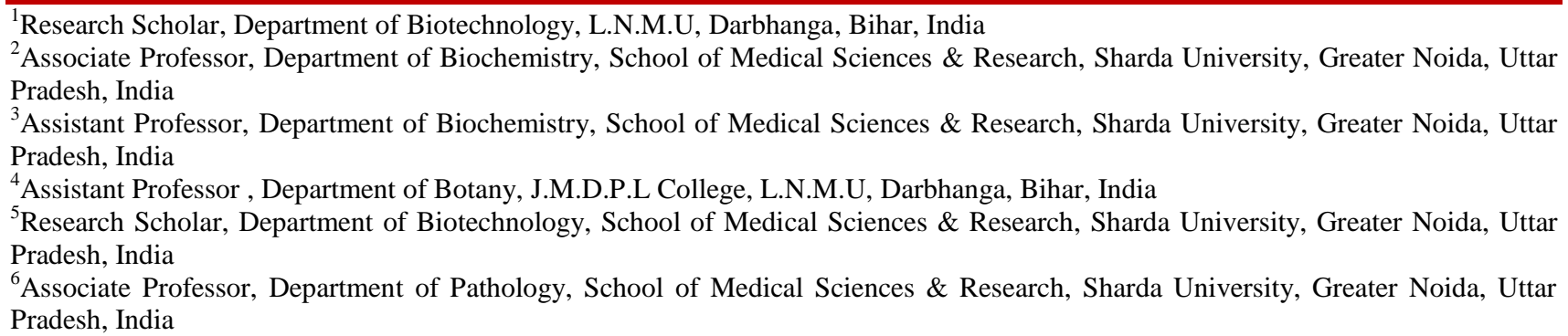

DOI: $10.36347 /$ sajb.2022.v10i01.001

| Received: 31.11 .2021 | Accepted: 03.01.2022 | Published: 10.01.2022

*Corresponding author: Dr. Shailza Verma

Associate Professor, Department of Biochemistry, School of Medical Sciences and Research, Sharda University, Greater Noida, Uttar Pradesh, India

\section{Abstract}

\section{Original Research Article}

The various sources are generating a lot of polluting materials in the ponds water of Harahi \& Gangasagar in the district of Darbhanga in Bihar. The sources are domestic drainagesthat directly discharge night soil from houses, medical wastes from doctor's clinic as well as industrial garbage. It is due to the presence of houses, clinics, some industries near the Harahi and Gangasagar ponds. These wastes are very dangerous and hazardous in nature on one hand, and at the other hand may contain a lot of valuable materials which protect our environment. In view of safety, it is essential to treat these wastes properly to protect the environment. There are various ways by which toxic and valuable by-products can be separated. The toxic products can be properly discarded and valuable products can be effectively utilized. The authors present the physicochemical analysis of Harahi and Gangasagarpond water. The results obtained have been compared with standard values of "Bureau of Indian standard permissible limit for drinking water."

Keywords: Pollution, physico-chemical analysis, domestic drainage, industrial effluents, pharmaceutical wastes, toxic and hazardous.

Copyright (C) 2022 The Author(s): This is an open-access article distributed under the terms of the Creative Commons Attribution 4.0 International License (CC BY-NC 4.0) which permits unrestricted use, distribution, and reproduction in any medium for non-commercial use provided the original author and source are credited.

\section{INTRODUCTION}

Darbhanga is one of the fastest growing cities in Bihar with rapid development and exploding population resulting in urbanization [1]. As result of population explosion pollution is the biggest problem in this city.

Pollution produced by people in turn affects them that make it a serious social problem [2]. Pollution production has two facts. One is the inevitable by production which is governed by natural laws. It therefore, cannot be stopped or cured without reducing the population [3]. By-product accumulation can be altered somewhat although it is debatable whether treatment measures would be significant without decreasing population growth. This type of pollution will be referred to as first order pollution.

The second fact will be referred to as the second order pollution or waste accumulation and implies waste that is formed as a result of man's technological activities. The amount of secondary waste is also directly related to the population size.

Pure water is not found in nature. Even rain water which is in fact distilled water, collect impurities such as dust, gases, bacteria etc. during its passage through atmosphere. Thus it has to be analysed in order to ascertain its quality. 
Pollution may be natural or artificial. The artificial pollution forms the major part andis caused as a result of manmade activities. Artificial pollution is mainly caused by wastes from households, industries and agriculture lands. The domestic wastes include human excreta, urine, kitchen, washing and laundry wastes which do not receive any treatment and are directly discharged into reservoirs or water course. The above said problem is particularly significantin small town like Darbhanga which are situated close to flowing ponds and have poor sewer facilities. Darbhanga is locally considered as a town of ponds with many ponds available in and around the whole town. Nearly dozens of ponds are situated in this town. Additionally, there is no doubtthat several diseases in men and animals are obtained from waste water from corporations, municipalities, slaughtering plants and boats sanatoria etc.

Several diseases in humans like cholera and typhoid spread by polluted water. Dr John in 1850 , reported that cholera epidemic were the result of some micro-organism present in the faces of cholera victim [4]. A study was carried out in the Ipswich and Shawsheen river basin in order to find out a relation between the number of septic tank disposal system in the drainage basins and few parameters describing the water quality of the drainage [5]. The results showed that the amount of dissolved solids in the basic flow of stream was depended on housing density [6].

The present study is a comparative account of the quality of water at Harahi and Gangasagar ponds of Darbhangatown in three different seasons namely summer, winter and rainy season.

The average of the three values thus obtained was taken into study.

\section{MATERIALS AND METHODS \\ Collection of samples}

The samples were collected from Harahi\&Gangasagar ponds and labelled as inlet of waste water into ponds $\left(\mathrm{S}_{1} \mathrm{H}, \mathrm{S}_{1} \mathrm{G}\right)$, outlet of waste water $\left(\mathrm{S}_{2} \mathrm{H}\right.$, $\left.\mathrm{S}_{2} \mathrm{G}\right)$ and mid pond $\left(\mathrm{S}_{3} \mathrm{H}, \mathrm{S}_{3} \mathrm{G}\right)$, hand pump near ponds $\left(\mathrm{S}_{4} \mathrm{H}, \mathrm{S}_{4} \mathrm{G}\right)$, drinking water from industrial area $\left(\mathrm{S}_{5} \mathrm{H}\right.$, $\left.\mathrm{S}_{5} \mathrm{G}\right)$, industrial waste water like Aluminium-factory $\left(\mathrm{S}_{6} \mathrm{H}, \mathrm{S}_{6} \mathrm{G}\right)$ and pharmaceutical company or wastes flowing in ponds $\left(\mathrm{S}_{7} \mathrm{H}, \mathrm{S}_{7} \mathrm{G}\right)$.

\section{Sampling of water}

Five-litre capacity plastic containers with lid were taken for the collection of water samples. These containers were washed with $(1: 1)$ HCL by dipping for 24 hours. Then thoroughly cleaned with tap water and finally with distilled water. The containers were not opened before the time of filling. At the sampling sites, the containers were first rinsed with sample water and then the samples were taken from the designated site i.e. the middle or banks of ponds and at the depth of ten inches below the surface of water. These water samples from ponds, tube well and other selected sites were collected in all the three seasons winter, summer and rainy.

The samples were taken by holding containers in the hand near its base and plunging its neck downward below the surface. The containers were turned until the neck points slightly upward, the mouth being directed against the current 500 to $600 \mathrm{ml}$ samples were taken in each container and which were later labelled immediately with complete details. The samples were preserved by adding $2 \mathrm{ml}$ conc. $\mathrm{H}_{2} \mathrm{SO}_{4}$ per litre. The time and temperature of the selected sites were noted. For the analysis of oil and grease, the samples were taken in wide mouthed saline bottles.

\section{Analysis}

The collected samples were analysedfor different parameters soonafter collection. The parameters tested included $\mathrm{pH}$, turbidity, electrical conductivity (EC), total dissolved solids (TDS), alkalinity, total hardness, dissolved oxygen (DO), biological oxygen demand (BOD) and chemical oxygen demand (COD). The concentration of different ions like calcium, magnesium, potassium, sodium, iron, sulphates, fluoride, chloride and phosphates (total and dissolved) was also analysed in the representative samples. Standard methods recommended by APHA (2005) were followed for the analyses.

The results were tabulated in Table $1,2 \& 3$. The results have been compared with the values given by the standard values for drinking watersuggested in the Bureau of Indian standard (BIS 1991).

\section{RESULTS}

The pound water is largely influenced by pollution particularly in urban cities. It has large effect on physical and chemical properties of water. Many biotic and abiotic component of ecosystem are changed. The physical characteristics of turbidity, TDS (mg/L), electrical conductivity $(\mathrm{mho} / \mathrm{cm})$ and $\mathrm{pH}$ was studied from 7 sites of Ganga Sagar and Harahi pounds of Darbhanga district (Table 1).

The chemical reactions studied in pond water included alkalinity $(\mathrm{mg} / \mathrm{L})$, total hardness $(\mathrm{mg} / \mathrm{L})$ oil and grease $(\mathrm{mg} / \mathrm{L})$ dissolved oxygen $(\mathrm{DO})$ of water in $\mathrm{mg} / \mathrm{L}$, chemical oxygen demand (COD) of water in $\mathrm{mg} / \mathrm{L}$ and biological oxygen demand (BOD) of water in $\mathrm{mg} / \mathrm{L}$ (Table 2).

The concentration of cations/anions including calcium, magnesium, sodium, potassium, iron, fluoride, chloride, sulphates, total phosphates, dissolved phosphates were studied (Table 3 ). 
Table 1: Physical parameters for drinking water, ponds water and Industrial effluents during rainy season

\begin{tabular}{|c|c|c|c|c|c|c|c|c|c|c|c|c|c|c|c|c|}
\hline Parameters & $\mathbf{S}_{1} \mathrm{H}$ & $S_{1} \mathbf{G}$ & $\mathbf{S}_{2} \mathbf{H}$ & $\mathbf{S}_{2} \mathbf{G}$ & $\mathbf{S}_{3} \mathbf{H}$ & $\mathbf{S}_{3} \mathbf{G}$ & $\mathrm{S}_{4} \mathrm{H}$ & $\mathbf{S}_{4} \mathbf{G}$ & $\begin{array}{l}\mathbf{S}_{5} \\
\mathbf{H}\end{array}$ & $\begin{array}{l}S_{5} \\
G\end{array}$ & $\mathrm{~S}_{6} \mathrm{H}$ & $S_{6} G$ & $\mathbf{S}_{7} \mathbf{H}$ & $\mathbf{S}_{7} \mathbf{G}$ & $\begin{array}{l}\text { Desirabl } \\
\text { e Limits }\end{array}$ & $\begin{array}{l}\text { Permissibl } \\
\text { e Limits }\end{array}$ \\
\hline Turbidity & 46 & 47 & 55 & 55 & 52 & 53 & 4 & 3.5 & 3 & 2.5 & 14 & 14 & 25 & 25 & 5.0 & 10.0 \\
\hline $\begin{array}{l}\text { Electrical } \\
\text { Conductivit } \\
\text { y in } \\
\mathrm{mho} / \mathrm{cm}\end{array}$ & $\begin{array}{l}125 \\
4\end{array}$ & $\begin{array}{l}125 \\
3\end{array}$ & $\begin{array}{l}117 \\
4\end{array}$ & $\begin{array}{l}117 \\
6\end{array}$ & 887 & 856 & $\begin{array}{l}124 \\
4\end{array}$ & $\begin{array}{l}124 \\
5\end{array}$ & 767 & 765 & $\begin{array}{l}145 \\
5\end{array}$ & $\begin{array}{l}146 \\
0\end{array}$ & $\begin{array}{l}175 \\
5\end{array}$ & $\begin{array}{l}175 \\
6\end{array}$ & $50-800$ & $>800$ \\
\hline $\begin{array}{l}\text { Total } \\
\text { dissolved } \\
\text { solid (TDS) } \\
\text { mg/L }\end{array}$ & $\begin{array}{l}248 \\
2\end{array}$ & $\begin{array}{l}249 \\
1\end{array}$ & $\begin{array}{l}256 \\
7\end{array}$ & $\begin{array}{l}256 \\
5\end{array}$ & $\begin{array}{l}274 \\
8\end{array}$ & $\begin{array}{l}275 \\
6\end{array}$ & $\begin{array}{l}265 \\
4\end{array}$ & $\begin{array}{l}266 \\
0\end{array}$ & 856 & 858 & 879 & 880 & $\begin{array}{l}125 \\
5\end{array}$ & $\begin{array}{l}126 \\
0\end{array}$ & 300 & 600 \\
\hline $\mathrm{pH}$ & 6.1 & 6.4 & 6.9 & 6.87 & 6.3 & 6.35 & 6.20 & 6.24 & $\begin{array}{l}6.7 \\
3\end{array}$ & $\begin{array}{l}6.7 \\
1\end{array}$ & 8.4 & 8.7 & 6.24 & 6.24 & $6.6-8.5$ & $\begin{array}{l}\text { No } \\
\text { relaxation }\end{array}$ \\
\hline
\end{tabular}

Table 2: Chemical parameter for drinking water, ponds water and industrial effluents during rainy season

\begin{tabular}{|c|c|c|c|c|c|c|c|c|c|c|c|c|c|c|c|c|}
\hline Parameters & $\mathbf{S}_{1} \mathbf{H}$ & $S_{1} \mathbf{G}$ & $\mathbf{S}_{2} \mathrm{H}$ & $\mathbf{S}_{2} \mathbf{G}$ & $\mathbf{S}_{3} \mathbf{H}$ & $\mathbf{S}_{3} \mathbf{G}$ & $\mathbf{S}_{4} \mathbf{H}$ & $\mathbf{S}_{4} \mathbf{G}$ & $\mathbf{S}_{5} \mathrm{H}$ & $\mathbf{S}_{5} \mathbf{G}$ & $\mathrm{S}_{6} \mathrm{H}$ & $\mathbf{S}_{6} \mathbf{G}$ & $\mathbf{S}_{7} \mathbf{H}$ & $\mathbf{S}_{7} \mathbf{G}$ & $\begin{array}{l}\text { Desirable } \\
\text { Limits }\end{array}$ & $\begin{array}{l}\text { Permissible } \\
\text { Limits }\end{array}$ \\
\hline $\begin{array}{l}\text { Alkalinity } \\
\text { mg/L }\end{array}$ & 544 & 556 & 500 & 510 & 356 & 367 & 452 & 455 & 298 & 292 & 267 & 270 & 136 & 132 & 200 & 600 \\
\hline $\begin{array}{l}\text { Total } \\
\text { Hardness } \\
\text { mg/L }\end{array}$ & 654 & 652 & 744 & 746 & 544 & 545 & 611 & 612 & 454 & 450 & 382 & 385 & 554 & 552 & 300 & 600 \\
\hline Oil \& Grease & 118 & 120 & 162 & 162 & 166 & 166 & 154 & 155 & 110 & 112 & 170 & 172 & 180 & 182 & - & - \\
\hline $\begin{array}{l}\text { DO } \\
\mathrm{mg} / \mathrm{L} \\
\end{array}$ & Nil & & Nil & & Nil & & 7.2 & 7.4 & 5 & 4.5 & 8 & 8 & Nil & & 10 & $\begin{array}{l}\text { Not less than } \\
10\end{array}$ \\
\hline COD mg/L & 75 & 75 & 60 & 60 & 67 & 67 & 74 & 73 & 67 & 66 & 92 & 94 & 121 & 124 & - & $\begin{array}{l}250 \text { Inland } \\
\text { or Surface } \\
\text { water }\end{array}$ \\
\hline BOD mg/L & 108 & 112 & 117 & 115 & 114 & 115 & 114 & 118 & 116 & 115 & 122 & 121 & 128 & 126 & 5 & 5 \\
\hline $\begin{array}{l}\text { TC } \\
\text { (MPN/100ml) }\end{array}$ & - & - & - & - & 2400 & 2200 & 440 & 435 & 34 & 30 & - & - & - & - & - & - \\
\hline $\begin{array}{l}\text { FC } \\
\text { (MPN/100ml) }\end{array}$ & - & - & - & - & 1400 & 1200 & 160 & 110 & 8 & 7 & - & - & - & - & - & - \\
\hline
\end{tabular}

Table 3: Concentration of cations/anions in drinking water ponds (Harahi \& Ganga Sagar) and industrial effluents in $\mathrm{mg} / \mathrm{L}$ during rainy season

\begin{tabular}{|c|c|c|c|c|c|c|c|c|c|c|c|c|c|c|c|c|}
\hline Parameters & $\mathbf{S}_{1} \mathbf{H}$ & $\mathbf{S}_{1} \mathbf{G}$ & $\mathbf{S}_{2} \mathbf{H}$ & $\mathbf{S}_{2} \mathbf{G}$ & $\mathbf{S}_{3} \mathbf{H}$ & $\mathbf{S}_{\mathbf{3}} \mathbf{G}$ & $\mathrm{S}_{4} \mathrm{H}$ & $\mathbf{S}_{\mathbf{4}} \mathbf{G}$ & $\mathbf{S}_{5} \mathbf{H}$ & $\mathbf{S}_{\mathbf{5}} \mathbf{G}$ & $\mathbf{S}_{6} \mathbf{H}$ & $S_{6} G$ & $\mathbf{S}_{7} \mathbf{H}$ & $\mathbf{S}_{7} \mathbf{G}$ & $\begin{array}{l}\text { Desirable } \\
\text { Limits } \\
\end{array}$ & $\begin{array}{l}\text { Permissible } \\
\text { Limits } \\
\end{array}$ \\
\hline Calcium & 87 & 86 & 92 & 91 & 66 & 64 & 70 & 72 & 80 & 85 & 56 & 54 & 98 & 97 & 75 & 200 \\
\hline Magnesium & 45 & 47 & 54 & 55 & 47 & 40 & 42.5 & 43.6 & 34.2 & 36 & 21 & 22 & 46 & 45 & 30 & 100 \\
\hline Sodium & 35 & 38 & 31 & 30 & 26 & 27 & 35 & 34 & 28 & 27 & 58 & 56 & 18 & 20 & - & - \\
\hline Potassium & 24.5 & 26 & 25.2 & 27 & 18.4 & 19 & 22.1 & 23.2 & 26 & 25 & 1.2 & 1.3 & 6.4 & 6.2 & - & - \\
\hline Iron & 1.3 & 1.2 & 2.1 & 2.4 & 1.32 & 1.4 & 2.4 & 3.2 & 4.2 & 4.5 & 1.2 & 2.1 & 1.3 & 2 & 0.3 & 1.0 \\
\hline Fluoride & 1.12 & 1.20 & 1.20 & 1.24 & 2.73 & 2.75 & 0.46 & 0.48 & 0.98 & 0.98 & 1.62 & 1.60 & 1.52 & 1.54 & 1 & 1.5 \\
\hline Chloride & 78 & 77 & 42 & 46 & 92 & 90 & 116 & 115 & 18 & 18 & 16 & 15 & 19 & 18 & 250 & 1000 \\
\hline Sulphate & 0.42 & 0.44 & 0.52 & 0.54 & 0.32 & 0.30 & 0.45 & 0.44 & 0.21 & 0.22 & 0.46 & 0.45 & 0.38 & 0.34 & 200 & 400 \\
\hline $\begin{array}{l}\text { Total } \\
\text { phosphate }\end{array}$ & 1.2 & 1.10 & 0.28 & 0.30 & 0.78 & 0.80 & 0.42 & 0.44 & 0.20 & 0.22 & 0.32 & 0.32 & 0.78 & 0.78 & - & - \\
\hline $\begin{array}{l}\text { Dissolved } \\
\text { Phosphate } \\
\end{array}$ & 0.60 & 0.62 & 0.20 & 0.21 & 0.24 & 0.24 & 0.16 & 0.16 & 0.12 & 0.12 & 0.18 & 0.18 & 0.28 & 0.28 & - & - \\
\hline
\end{tabular}

\section{DISCUSSION}

In our study the maximum turbidity was noted at sampling sites $\mathrm{S}_{2} \mathrm{H}$ and $\mathrm{S}_{2} \mathrm{G}$ of 55 each. The minimum turbidity was noted at $\mathrm{S}_{4} \mathrm{H}$ of 4 . Turbidity of pond water varies from almost zero to highly turbid, depending on the amount of suspended particles. High turbidity makes pond water unsuitable for acquatic life [7].

The maximum electrical conductivity (mho/cm) was noted at sampling site $\mathrm{S}_{7} \mathrm{G}$ and minimum at $\mathrm{S}_{5} \mathrm{G}$ with values 1756 and 765 of respectively in this study. Water becomes a conductor of electric current due to substances are dissolved in it and its conductivity is proportionate to the amount of the substances dissolved in it [8]. The conductivity of these substances depends on their charges.Conductivity measurement is useful in monitoring the total salt level in pure water supply line, in river, lakes and ponds and effluent discharge channels [9].

The maximum $\mathrm{pH}$ was noted $\mathrm{atS}_{6} \mathrm{G}$ and minimum at $\mathrm{S}_{1} \mathrm{H}$ with 8.7 and 6.1 of respectively. $\mathrm{pH}$ effect bacteria and decomposition in a pond. Most useful bacteria cannot survive overly acidic water. Moreover, high $\mathrm{pH}$ may also increase the toxicity of other substances. 
The sum of all the chemical ions dissolved in the water is called total dissolved solids or TDS [10]. TDS is controlled by the natural source of pond water and by nearby land use activities. The highest TDS of pond water was noted at $\mathrm{S}_{3} \mathrm{G}(2756 \mathrm{mg} / \mathrm{dl})$ and minimum at $\mathrm{S}_{5} \mathrm{H}$ of $856 \mathrm{mg} / \mathrm{dl}$.

In our study it was found that alkalinity of water was maximum at $\mathrm{S}_{1} \mathrm{G}$ i.e. $556 \mathrm{mg} / \mathrm{L}$ while it was minimum at $\mathrm{S}_{7} \mathrm{G}$ i.e. $132 \mathrm{mg} / \mathrm{L}$. The main source of alkalinity of water are carbonate, bicarbonate and hydroxide compounds. The alkalinity of water on one hand may act as buffer and on the other hand high alkalinity may lead to gastrointestinal problems and skin irritation.

The maximum biochemical oxygen demand (BOD) of the sample was observed at sites $\mathrm{S}_{7} \mathrm{H}$ (128 $\mathrm{mg} / \mathrm{dl})$. BOD is a good index of pollution and therefore helps in deciding the suitability of water for consumption [11].

The COD of water means amount of oxygen required to oxidise organic matter. It is indicator for sewage and water pollution. The maximum value of COD varied from $64.07 \mathrm{mg} / \mathrm{l}$ to $86.70 \mathrm{mg} / \mathrm{l}$ and the maximum value was observed at $\mathrm{S}_{6} \mathrm{G}(94 \mathrm{mg} / \mathrm{dl})$. Total hardness of pond water was found maximum at site $S_{2} G$ $746.0 \mathrm{mg} / \mathrm{l}$.

Dissolved oxygen (DO) is an important parameter of water quality which reflects physical and biological processes taking place in water. High level of DO causes speed up corrosion in water pipes levels lower than $10 \mathrm{mg} / \mathrm{dl}$ are not permissible for human use.The low value of DO may be due to pollution load, organic matter and photosynthetic activity.The total coliform (TC) and total coliform (FC) were also reported at few sites. The similar findings were studied by Sinha $\mathrm{D}$, Arya $\mathrm{S}$ et al., at their independent studies $[12,13]$.

In our study calcium was minimum at $\mathrm{S}_{6} \mathrm{G} 54$ $\mathrm{mg} / \mathrm{dl}$ and magnesium at $\mathrm{S}_{6} \mathrm{H} 21 \mathrm{mg} / \mathrm{dl}$. Lowest sodium was recorded at $\mathrm{S}_{7} \mathrm{H} 18 \mathrm{mg} / \mathrm{dl}$ and highest at $\mathrm{S}_{6} \mathrm{H} 58$ $\mathrm{mg} / \mathrm{dl}$. Potassium was highest at $\mathrm{S}_{2} \mathrm{G} 27 \mathrm{mg} /$ dland lowest at $\mathrm{S}_{6} \mathrm{H} 1.2 \mathrm{mg} / \mathrm{dl}$. Iron ranged from 1.2-4.5 mg/dl.Our results were concordant with the studies by Bhagat $\mathrm{P}$, Bhuiyan J et al., [14, 15].

\section{CONCLUSION}

It is finally concluded on the basis of above results and discussions that the water of Harahi and Ganga Sagarponds is not suitable for the human consumption. It is very much feared that this contaminates the ground water which is fatal for the public health and environment.

Conflict of Interest: The authors have no conflicts of interest regarding this investigation.
In authors are very much thankful to the Departmentand H.O.D. of Botany, Darbhanga University who have provided all the possible facilities for successful completion of this research work.

\section{REFERENCES}

1. Economic and social commission for western Asia (2003). September 11.

2. United Nations, United Nations Economic and Social Commission for Western Asia (2011) ESCWA.

3. Central pollution control Board Report (2005).

4. Shannon, B. (2017). Status of sewage treatment plants in Ganga basin, Central Pollution Control Board, 2001.

5. Trevadi, R. K., \& Goel, P. K. (1986). Chemical and Biological methods for water pollution studies, environmental publication, Karad. Maharashtra and India.

6. Kodarkar, M. S. (1992). Methodology for water analysis, physico-chemical, Biological and Microbiological Indian Association of Aquatic Biologists Hyderabad; Pub.2: pp. 50. APHA. (1985). Standard Methods for Examination of Water and Wastewater, 20th Edition, American Public Health Association, Washington D. C.

7. Kadam, M. S., Pampatwar, D. V., \& Mali, R. P. (2007). Seasonal variations in different physico-chemical characteristics in Masoli reservoir of Parbhani district, Maharashtra. J Aquatic Biol, 22(1), 110-112.

8. Kamble, S. M., Kamble, A. H., \& Narke, S. Y. (2009). Study of physico-chemical parameters of Ruti dam, Tq. Ashti, dist. Beed, Maharashtra. J. Aqua. Biol, 24(2), 86-89.

9. Hujare, M. S. (2008). Seasonal variation of physico-chemical parameters in the perennial tank of Talsande, Maharashtra. Ecotoxicology and Environmental monitoring, 18(3), 233-242.

10. Swaranlatha, N., \& Rao, A. N. (1998). Ecological studies of Banjara Lake with reference to water pollution. Journal of environmental biology, 19(2), 179-186.

11. Mani, S., Sahu, K. K. (2020). Physico-chemical analysis of ponds and river water in Darbhanga, IJCRT, 12, 1428-1433.

12. Deepak, S. (2018). Assessment of Physiochemical Properties of Pond Water in Bemetara Town of Chhattisgarh State.

13. Sandeep, A., Vinit, K., Madhullica, R., \& Anshu, D. (2011). Physico-chemical analysis of selected surface water samples of Laxmi Tal (pond) in Jhansi city, UP, Bundelkhand region, Central India. Journal of Experimental Sciences, 2(8), 1-6.

14. Bhagat, P. R. (2008). Study of physico-chemical characteristics of the accumulated water of pond of Lohara, at Yavatmal (MS). Rasayan Journal of Chemistry, 1(1), 195-197.

15. Bhuiyan, J. R., \& Gupta, S. (2007). A comparative hydrobiological study of a few ponds of Barak Valley, Assam and their role as sustainable water resources. Journal of Environmental Biology, 28(4), 799-802.

\section{ACKNOWLEDGMENTS}

